\title{
CONSIDERAÇÕES EM TÔRN DE UM LIVRO DO Pe. SERAFIM LEITE SÔBRE A FUNDAÇÃO DE SÃO PAULO (1).
}

O Autor que goza de grande reputação no nosso meio intelectual por ter publicado entre outros trabalhos, a magnífica $H$ istória da Companhia de Jesús no Brasil, teve a feliz idéia de contribuir com o livro que ora vamos apreciar para o enriquecimento das primeiras páginas da nossa História no que tange a fundação. de São Paulo de Piratininga, justamente agora que comemoramos - IV Centenário do nascimento dessa metrópole que é o orgulho não só dos paulistas, como de todos os brasileiros.

O trabalho do Autor divide-se em seis capítulos e dois apêndices. No primeiro capítulo, devidamente comentada, está transcrita uma carta de um Irmão, datada de São Vicente, de 10 de março de 1553, descrevendo a viagem de Nóbrega desde a Bahia até São Vicente. Também reproduz comentada, uma carta de Nóbrega ao padre Simão Rodrigues, provincial da ordem em Portugal, datada de São Vicente, de 10 de março de 1553. O segundo capítulo ocupa-se do primeiro mestre-escola (primária) de São Paulo, Augusto Rodrigues e. o terceiro, do mestre de latim, José de Anchieta. No quarto capítulo encontra-se a carta que êste escreveu aos irmãos enfermos, datada de São Vicente, em 20 de março de 1555. Documentos inéditos sôbre São Paulo de Piratininga é o título do quinto capítulo. E, finalmente, o sexto capítulo é intitulado: Nóbrega fundador de São Paulo. No apêndice $A$ vem transcrita uma carta de Nóbrega, datada de Sanfins (Minho), de 18 de junho de 1548, sôbre assunto que diretamente não interessa à história da fundação de São Paulo, de vez que diz respeito a nomeação dêsse jesuíta para o cargo de comendador do mosteiro de Sanfins. $O$ apêndice $B$ indica as datas do nascimento e morte de Nóbrega e ocupa-se de uma proposta aprovada em sessão do Instituto Histórico e Geográfico Brasileiro em 26 de maio de 1928, que cuida da ereção de uma estátua a Nóbrega na Esplanada do Castelo, no Rio de Janeiro.

Três datas são indicadas como a da fundação de São Paulo de Piratininga: 1532, 29 de agôsto de 1553, e 25 de janeiro de 1554 .

(1). Serafim Leite S. J. - Nóbrega e a fundação, de São Paulo. Instituto de Intercâmbio Luso-Brasileiro. Lisboa, 1953. 123 pápinds. 
Tratando-se da vila que teria Martim Afonso de Sousa fundado no planalto em 1532, discute-se onde tenha sido o local para isso escolhido. Uns opinam que foi em lugar incerto às margens do rio Pinheiros; outros, como Afonso de Freitas, em uma área situada entre os bairros da Luz, Bom Retiro e Campos Elíseos (2); e finalmente há os que sustentam que essa vila ocupou parte. da colina onde hoje está edificado o centro urbano de São Paulo. No que todos estão de acôrdo, é que essa vila não teve vida municipal efetiva, ou se a teve, foi efêmera, dispersando-se os seus. moradores.

Para nós, a vila martim-afonsina desapareceu de todo e isso durante a própria estadia do donatário em São Vicente. Como sabemos, partiu Martim Afonso depois de 4 de março de 1553 - a moção para o norte começava em fins de março -, e chegou a Portugal mais ou menos em agôsto. Dêste país seguiu, logo no ano seguinte, para a India e nunca mais tornou à sua Capitania. que, de resto, só lhe foi doada depois de sua partida.

Pois bem. Antes de partir de São Vicente, vedou Martim Afonso o acesso ao planalto aos colonos de São Vicente! Palavras. de Nóbrega, não exatamente as da carta ao rei D. João III, mas as de uma outra a Santo Inácio de Loiola, mais ou menos entre janeiro a 23 de maio de 1556, encerram decisiva confirmação para o raciocínio de Frei Gaspar da Madre de Deus, menos, já se vê, quanto à negativa da fundação e brevíssima existência da Vila de Piratininga durante a permanência de Martim Afonso em São Vicente.

"Se Martim Afonso tivera fundado a Vila de São Paulo, escreve Frei Gaspar (nós diriamos: se a povoação fundada por Martim Afonso não tivesse sido por êle extinta, após a deserção de seus povoadores) - , seria desnecessária a referida permissão (de poderem os colonos de São Vicente subir ao planalto) de sua Procuradora (D. Ana Pimentel, em 1554). Em tal caso poderiam entrar. e sair quantos portuguêses quisessem subir aos Campos de Piratininga, por não caber no juízo de pessoa algúma, que naquela paragem se havia de criar uma vila inacessível aos compatriotas de seus moradores (3).

Eis as palavras de Nóbrega: "Ali (onde os jesuítas "tem casas e igrejas"... "perto da Vila de Santo André", e onde "todos os cristãos desejam... viver, se lhes dessem licença) foi a primeira povoação de cristãos, que nesta terra hoưve em tempo de Martim Afonso, e vieram viver ao mar, por razão dos navios, dé que todos se arrependeram, e, todavia a alguns deixaram lá ir viver" (4). Lògicamente está aqui subentendida a proibição feita aos portu-

(2). - J. P. Leite Cordeiro, Frases Esparsas, primeira série, Säo Paulo, 1952, pág. 158.

(3). - Frei Gaspar da Madre de Deus, Memórias para a história da capitania de São Vicente, terceira ediçāo, cf. Idem, Ibidem, 177-179 e 217-218.

(4). - Cartas Jesuíticas, I, 154. 
guêses de viver naqueles lugares, proibição de que apenas João Ramalho foi isento, conforme assevera o mesmo Frei Gaspar.

Os cristãos encontrados em 1550, "derramados" pelo Campo, juntou-os Leonardo Nunes em duas etapas. Os últimos foram os que viviam nas "Aldeias dos Indios", distantes em média "quatro a cinco léguas" do lugar onde logrou que erguessem a Ermida de Santo André, como se pode crer. Tais cristãos só poderiam ter ido para lá, pelo menos legalmente, após a permissão concedida, com restrições ainda, por $\mathrm{D}$. Ana Pimentel, conforme o documento publicado por Frei Gaspar. E diz Leonardo Nunes dos portuguêses, encontrados nas sobreditas aldeias: "acabei com êles que se tornassem aos cristãos" (5).

Por sua vez, afirma Simão de Vasconcelos: "Esta foi a origsm da Casa; vejamos agora a das Aldeias. Tanto que os índios viram os portuguêses com residência feita naquelas suas terras, que estavam metidas da beira-mar para o sertão coisa de 12 léguas, lugar então desabitado totalmente dos portuguêses, desceram de boa vontade"... (6). Ora, aí mesmo diz êle que está acompanhando quase literalmente os Apontamentos de Anchieta. Este, na sua Quadrimestre de maio a setembro (os Apontamentos atualmente andam perdidos) escreve: "Outro (índio), que havia muito tempo se tinha feito cristão com os portuguêses que outrora moraram nesta aldeia (de Piratininga) (7).

Assim, pois, não deixa de ser uma extravagância a opinião de Jaime Cortesão erigindo Martim Afonso de Sousa em percursor genial da "Geopolítica Portuguêsa", de vez que a importância que êle dava ao Brasil e a sua própria Capitania, está nitidamente expressa no seguinte tópiro da carta que de Diu (India), escreveu a 14 de dezembro de 1535 ao conde de Castanheira: "Pero Lopes me escreveu que vossa senhoria queria um pedaço dessa terra do Brasil que eu lá tenho, mande-a tomar tôda ou a que quiser que essa será para mim a maior mercê e a maior honta do mundo" (8).

Diz o Autor (página 79) que a 29 de agôsto de 1553, após três meses da sua chegada ao planalto, tendo escolhido Nóbrega Piratininga para reunir três tabas de selvícolas, fundou a aldeia, reunindo os índios pelo vínculo solene do catecumenato "no melhor lugar que se podia escolher". E acrescenta: "A fundação da Aldeia de Piratininga é a certidão de idade de São Paulo, não ainda a do seu batismo, porque a nova povoação só "daí a alguns meses se batizaria. $A$ certidão de batismo é a 25 de janeiro de 1554, em que a CasaColégio se inaugurou e se dedicou a São Paulo, nome que prevaleceu ao de Piratininga".

\footnotetext{
(5). - Cartas Jesuíticas, II, 61 e 62 .

(6). - Vida do Padre João de Almeida, página 73.

(7). - Cartas Jesuíticas, III, 49.

(8). - História da Colonização Portuguêsa do Brasil, III, 107.
} 
Em que documento se baseia o Autor para fazer tão arriscada afirmativa? No seguinte tópico da carta que Nóbrega escreveu de São Vicente a 30 de agôsto de 1553 ao padre Luiz Gonçalves da Câmara, provincial dos jesuítas em Portugal: "Ontem que foi dia da degolação de São João Batista, vindo, a uma aldeia, onde se ajuntam novamente e apartam os que se convertem e onde pus dois irmãos para os doutrinar, fiz solenemente uns $\mathbf{5 0}$ catecúmenos, dos quais tenho boa esperança de que serão bons cristãos e merecerão o batismo e será mostrada por obras a fé que tomaram agora".

Ora, como se pode fàcilmente notar, Nóbrega não faz a menor alusão a ter sido celebrada a missa que, para o Autor, é condição "sine qua non" para que a Aldeia de Piratininga tenha sido fundada a 29 de agôsto de 1553. Em abôno desta nossa opinião, citamos o seguinte tópico de um magnífico trabalho do padre Hélio Viotti S. J. publicado a 31 de janeiro do corrente ano no "Diário de São Paulo" sob o título $A$ fundação de São Paulo pelos jesuítas: "Quanto ao que pretendeu Nóbrega exprimir ao dizer "Fiz solenemente uns 50 catecúmenos", pode-se discutir. Terá a solenidade consistido nas cerimônias do ritual antigo, que ainda a êsse tempo andava impresso, por exemplo, no missal de Bérgamo? Teria sido apenas exterioridades outras, mais ou menos aparatosas, sem cunho pròpriamente litúrgico? Missa é que nunca foi cerimônia de receção de catecúmenos. Isto é certo. Se aí a tivesse aliás celebrado Nóbrega, não se explica como Anchieta, que cinco meses depois tratou com êsses mesmos índios e teve como discípulos aos companheiros de Nóbrega nessa excursão, pudesse repetidamente afirmar que a missa de 25 de janeiro de 1554, com que se inaugurou o Colégio de São Paulo, fôsse a primeira que se celebrou em Piratininga".

J. Polanco, secretário de Santo Inácio de Loiola, resumiu as cartas de Nóbrega e de outros membros da Companhia de Jesús, recebidas de São Vicente, no que diz respeito a pretensa Aldeia de Piratininga fundada por Nóbrega, escrevendo: "Num certo campo, doze léguas distante de São Vicente, três aldeias de brasis haviam determinado reunir-se e fixar sua morada para poderem ser, todos. juntos, catequizados pelos nossos e mostravam grande vontade de ouvir a palavra de Deus e aprender as coisas da fé. Depois que os brasis das sobreditas aldeias se reuniram em um mesmo lugar, antes que o padre Nóbrega deixasse a vila de São Vicente, a êles se dirigiu no mesmo dia da degolação de São João Batista, chegando a êsse lugar, onde habitavam separadamente os que se convertiam à fé de Cristo" (9). Portanto os frágeis argumentos: de que se serve o Autor para emprestar a Nóbrega o título de fundador da Aldeia de Piratininga, esboroam-se como um castelo de

(9). - J. Polanco, Chronicon S. J., III, 472. 
cartas. Aliás, êsse aldeiamento de índios que, conıu iź vimus, não se realizou pelos esforços de Nóbrega, desfêz-se em 1556 (10).

Os panegiristas de Nóbrega lhe atribuem a tomada de uma série de acertadas providências, tudo com muita antecedência, visando a fundação do Colégio. Porém nada há que prove que a idéia da fundação dêste tenha precedido à chegada do refôrço de membros da Companhia de Jesús, em que veio para São Vicente - jovem José de Anchieta. Tanto Vasconcelos (11) como A. Franco (12), claramente relacionam essa resolução com essa chegada e a notícia da ereção da Província, que não podia ser conhecida antes dessa oportunidade. Vasconcelos dá notícia de uma consulta realizada por Nóbrega em São Vicente após o Natal de 1553. Essa consulta está confirmada no De prima Collegii Fluminis Januarii institutione, c. $20^{\circ}$ do P. Antônio de Matos, trecho publicado pelo padre Hélio Viotti S. J. no suplemento do "Correio Paulistano" de 23 de agôsto de 1953. Com essa exposição dos fatos concorda o texto anchietano da Quadrimestre de maio a setembro (13).

Não nega o Autor e nem podia negar, diante dos documentos que conhecemos, que a ida de Nóbrega a Maniçoba tinha em vista explorar o caminho do Paraguai, pois a missão aos Carijós, ou a "emprêsa do Paraguai" era o projeto que então o obsessionava: "São Paulo de Piratininga e Maniçoba... eram marcos avançados, postos no interior, a caminho do Paraguai, onde resolutamente tencionava ir" (14).

A resolução de fundar em Piratininga o Colégio, foi coisa de última hora, e não tinha para Nóbrega o caráter de uma medida definitiva. Prova-se pelo fato de que para a instalação do mesmo, nada se preparara senão uma misérrima choupana: só em setembro ficou decidido construir nova habitação (15); a base agrícola, para a manutenção do Colégio, só é mencionada em carta de Nóbrega do ano de 1556 (16). Carta do mesmo Nóbrega dirigida a Luiz da Grã, de que êste nos dá notícia, como recebida na Bahia em outubro de 1554 (17), lhe significava ser "determinação" sua conservar no Brasil apenas duas casas: Bahia e São Vicente (18), esta última por ser a porta para Guaira. Ainda em 1557, "continuava a insistir em Lisboa pela ida ao Paraguai" (19). E mesmo depois de se ter decidido a mandar pedir terras para a manutenção do Colégio, ainda em 1559 escreve: "es-

(10). - Anchieta, Cartas, 92-93; Luiz da Grä, Novas Cartas Jesuiticas, 182-183; Nóbrega, Novas Cartas Jesuíticas, 105.

(11). - Crônica da Companhia de Jesús, I, I, n. 148.

(12): - Imagem de Coimbra, II, 232.

(13). - Anchieta, Cartas, 38.

(14): - Serafim Leite S. J., História da Companhia de Jesús no Brasil, I, 339

(15). - Anchieta, Cartas, 43.

(16): - Cartas do Brasil, 153

(17). - Novas Cartas Jesuíticas, 161, N.; a data ai indicada foi posteriormente retifi-

(18). - Cada por 163 .

(19): - Serafim Leite s. J., obra citada, I, 342. 
tou muito arrepenaido de não haver já tirado meus irmãos de lá", isto é, da Capitania de São Vicente, portanto também de São Paulo de Piratininga (20).

A ausência de Nóbrega a 25 de janeiro de 1554, quando de fato se fundou São Paulo, é suficientemente expressiva da importância muito secundária, que para êle revestia êsse acontecimento. Essa ausência se deduz claramente da interpretação óbvia de todos os documentos que se referem à fundação. J. Polanco aliás na sua Crônica (IV, 262), texto citado pelo padre Hélio Viotti S. J. no suplemento do "Correio Paulistano" de 6 de setembro de 1953, afirma expressamente, - e ninguém devia estar melhor informado sôbre isso que o secretário de Santo Inácio, - que a residência de Nóbrega nesse ano de 1554, continuava a ser em São Vicente, donde por vêzes ia em visita a Piratininga. O primeiro. documento, que o menciona como presente pouco antes em Piratininga é a carta de Pero Correia, de 18 de julho, escrita em São Vicente (21).

Todos êsses fatos devidamente documentados, não deixam de deslustrar o papel de Nóbrega na fundação da nossa São Faúo de Piratininga que, alguns excêntricos historiógrafos chamam agora de cidade nobreguense.

Recapitulando tudo, temos: a) - que em 1532 Martim Afonso de Sousa fundou uma vila em lugar incerto no planalto e que disso logo se arrependeu, tanto assim que antes de partir para Portugal em março de 1553 , vedou o acesso ao planalto aos habitantes de São Vicente; b) - que ao contrário do que o Autor sustenta, em 29 de agôsto de 1553 não fundou Nóbrega nenhuma aldeia nos campos de Piratininga, mas sim encontrou nesse local reunidos os selvícolas de três tabas; c) - que a 25 de janeiro de 1554 é que foi inaugurado o colégio erigido por ordem de Nóbrega e celebrada a primeira missa nos campos de Piratininga.

Para os que cuidam da História com carinho e sem se deixar contagiar pelo que escrevem ou dizem os aventureiros da erudição, a fundação do Colégio que inegàvelmente teve o poder de atrair como um imã ao seu derredor a população dispersa pelos campos. de Piratininga, foi o resultado de magnífico trabalho de uma selecionada equipe de membros da Companhia de Jesús, posteriormente auxiliada por João Ramalho que, entre o muito que fêz pela. prosperidade da povoação, a defendeu em julho de 1562 quando foi assaltada pelos selvícolas sob as ordens de Ururaí.

Dessa equipe, com exclusão de Nóbrega que mandou edificar - Colégio, os que mais se salientaram foram os seguintes: Leonardo. Nunes, inegàvelmente $o$ pioneiro dos catequistas, aquêle que palmilhou continuamente todo o planalto convertendo ao cristianismo

(20). - Cartas do Brasil, 218.

(21). - Novas Cartas Jesuíticas, 176. 
inúmeros aborígenes e preparando, por assim dizer, o terrero para que a boa sementeira germinasse; Manuel de Paiva, superior da equipe, que a 25 de janeiro de 1554, na choupana improvisada de 14 passos de comprimento por 10 de largura, feita de pau a pique e coberta de sapé, celebrou a primeira missa em São Paulo de Piratininga; e $o$ inconfundivel padre José de Anchieta que, embora jovem, pela sua elevada cultura humanista, foi escolhido para o cargo de mestre do Colégio, tendo sido seus discípulos os irmãos Afonso Braz, Vicente Rodrigues, Diogo Jácomo, Pedro Correia, Manuel de Chaves, Leonardo do Vale, Gaspar Lourenço, Gonçalo de Oliveira, Fabiano de Lucena, Antônio Rodrigues, Simão Gonçalves e outros. Permaneceu Anchieta durante 12 anos à testa do Colégio esforçando-se por torná-lo cada vez mais eficiente, sabendo que dessa eficiência dependia a vida de São Paulo de Piratininga. Após 44 anos de permanência ininterrupta no Brasil, aqui morreu êsse taumatugo deixando aos seus pósteros o maior exemplo de amor à raça aborígene, de apurado ascetismo e de inimitáveis abnegações, sendo por justo motivo apelidado - O Apostolo do Novo Mundo.

T. O. MARCONDES DE SOUZA.

Da Sociedade de Estudos Históricos e do Instituto Histórico e Geográfico de Sāo Paulo. 